MATEC Web of Conferences 47, 01008 (2016)

DOI: $10.1051 /$ matecconf/20164701008

(C) Owned by the authors, published by EDP Sciences, 2016

\title{
Identification of Bacteria and the Effect on Compressive Strength of Concrete
}

\author{
L. H. Anneza ${ }^{1}$, J. M. Irwan ${ }^{1, a}$, N. Othman ${ }^{2}$ and A. Faisal Alshalif ${ }^{1}$ \\ ${ }^{1}$ Jamilus Research Center, Universiti Tun Hussein Onn Malaysia, 86400 Parit Raja, Johor, Malaysia \\ ${ }^{2}$ Faculty of Civil and Environmental Engineering, Universiti Tun Hussein Onn Malaysia, 86400 Parit Raja, Johor, \\ Malaysia
}

\begin{abstract}
This paper presents the species of bacteria used in this study as well as the effect of the bacteria on compressive strength of bioconcrete. Bioconcrete is not only more environmentally friendly but it is easy to procure. The objective of this research is to identify the ureolytic bacteria and sulphate reduction bacteria that have been isolated and further use the bacteria in concrete to determine the effect of bacteria on compressive strength. Identification of bacteria is conducted through Polymerase chain reaction (PCR) method and DNA sequencing. The DNA of the bacteria was run through BLAST algorithm to determine the bacterial species.The bacteria were added into the concrete mix as a partial replacement of water. $3 \%$ of water is replaced by ureolytic bacteria and $5 \%$ of water is replaced by sulphate reduction bacteria. After running BLAST algorithm the bacteria were identified as Enterococcus faecalis (ureolytic bacteria) and Bacillus sp (sulphate reduction bacteria). The result of the compressive strength for control is $36.0 \mathrm{Mpa}$. Partial replacement of $3 \%$ water by ureolytic bacteria has strength of $38.2 \mathrm{Mpa}$ while partial replacement of $5 \%$ of water by sulphate reduction bacteria has strength of $42.5 \mathrm{Mpa}$. The significant increase of compressive strength with the addition of bacteria shows that bacteria play a significant role in the improvement of compressive strength.
\end{abstract}

\section{Introduction}

Bioconcrete is a combination of biology and concrete. In which, the biology part is the bacteria use in this research. Conventional way to increase strength without adding waste in concrete, normally relies on chemical solution or adding more cement. The alternative of using bacteria in concrete is gradually gaining more interest as a natural method to improve concrete properties and durability. Previous research conducted by Ghosh and Mandal [1], Muynck et al. [2], Tittelboom et al. [3] and Arunachalam et al. [4] has shown that adding bacteria into concrete does improve the strength as well as self healing of concrete. As bacteria are able to promote the precipitation of calcium carbonate in the form of calcite. Calcium carbonate precipitation occurs as a by-product of a common microbial metabolic process which would help increase the alkalinity and produce microbial calcite precipitation [5]. Nevertheless, the bacteria used by previous researchers are all from different sources and there are no specific or right bacteria added into the concrete. Therefore, this research aims to identify the bacteria that were previously isolated in [6] and use the bacteria in concrete to determine the effect of

\footnotetext{
${ }^{a}$ Corresponding author : irwan@uthm.edu.my
} 
the isolated bacteria on compressive strength. This study is based on previous study [7] which determines the optimum percentage of bacteria use.

\section{Materials}

The aggregate and sand used for this research were all carefully sieved according to BS 882.1992 [8]. Where the maximum size of aggregate used is $20 \mathrm{~mm}$ and sand is passing the $5 \mathrm{~mm}$ sieve. The cement used in this research is PCC (Portland composite cement). The ureolytic bacteria and sulphate reduction bacteria that are used in this study are taken from fresh urine and fresh acid mine water in Sg.Pelepah, Kota Tinggi, Johor, Malaysia respectively. The isolation and enrichment process are conducted as in Irwan [6]. After enrichment process, the bacteria are cultivated on agar plates to ensure the growth of bacteria. Figure 1 shows the ureolytic bacteria on the agar plate that is used in this research.

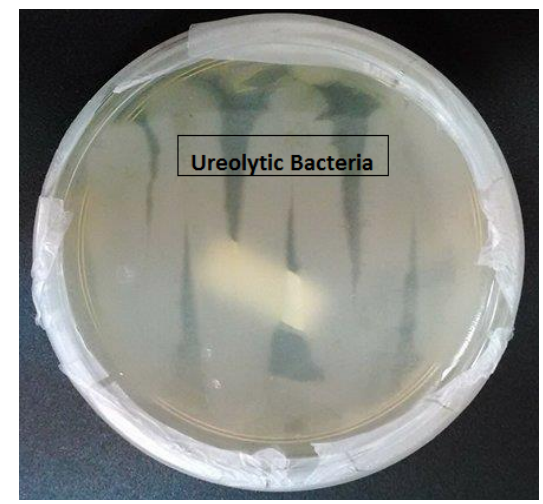

Figure 1. Agar plate with ureolytic bacteria.

\section{Methodology}

\subsection{Determining the type of bacteria}

The bacteria sample was first inoculated into Lysogeny Broth (LB) and incubated for 18 hours with temperature of $37^{\circ} \mathrm{C}$ and $400 \mathrm{rpm}$. The samples were then centrifuged to collect pellet for genome DNA extraction. The DNA is then quantified spectrophotometrically using a Nanodrop 2000 spectrophotometer (Fisher Scientific). Absorbance measurements were taken at $260 \mathrm{~nm}$ and $280 \mathrm{~nm}$ and used to calculate the DNA purity and concentration. $260 \mathrm{~nm}$ and $280 \mathrm{~nm}$ are wavelengths which are used to quantify amount of DNA in the samples. DNA samples were considered free from protein contamination if the $\mathrm{A}_{260}$ to $\mathrm{A}_{280}$ ratio was between 1.8 and 2.0. The result of the quantification is in Table 1. Based on the database using BLAST algorithm the bacteria used in this study which originally named sulphate reduction bacteria is Bacillus SP. Whereas, the proper nomenclature of ureolytic bacteria based on result after BLAST algorithm is Enterococcus faecalis.

Table 1. The concentration and the quality of DNA using Nanodrop.

\begin{tabular}{|c|c|c|c|c|c|}
\hline No. & Sample ID & Nucleic Acid Conc. & Unit & $\mathbf{2 6 0 / 2 8 0}$ & $\mathbf{2 6 0 / 2 3 0}$ \\
\hline 1 & $\mathrm{~S}$ & 165.1 & $\mathrm{ng} / \mu \mathrm{l}$ & 1.85 & 2.15 \\
\hline 2 & $\mathrm{U}$ & 159.7 & $\mathrm{ng} / \mu \mathrm{l}$ & 1.84 & 2.12 \\
\hline
\end{tabular}




\subsection{Preparation of inoculum to be casted in bioconcerete}

After preparing and sterilizing nutrient broth, 1 colony of bacteria is then added into the sterilized nutrient broth. The solution is then put into an orbital shaker and shaken for 10 days, which is the number of days required to achieve the maximum growth rate of both bacteria. The bacteria solution is then measured and used for casting concrete. Concrete casting is divided into batch 1-4, where each batch uses a different type of bacteria as well as control as a comparison. Figure 2 shows the bacteria solution which has been prepared in order to be used for bioconcrete casting. Solution on the left is ureolytic bacteria (Enterococcus faecalis) while the one on the right is sulphate reduction bacteria (Bacillus SP).

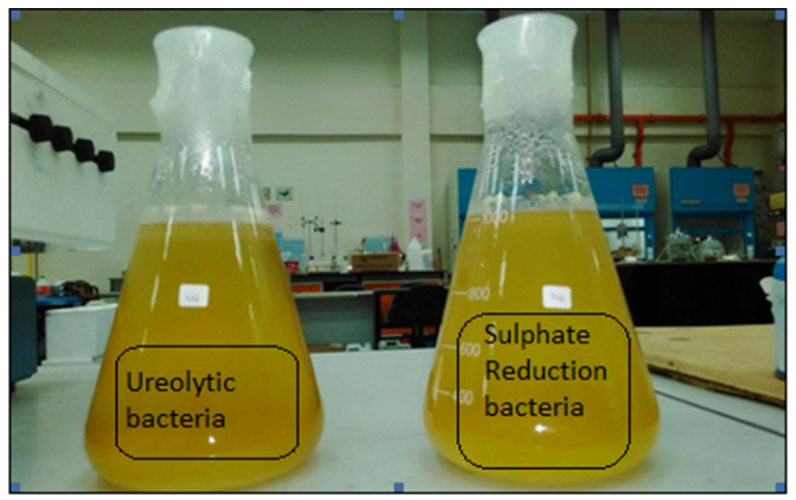

Figure 2. Ureolytic bacteria (Enterococcus faecalis) and sulphate reduction bacteria (Bacillus SP).

\subsection{Preparation and casting of bioconcrete}

The grade of concrete use in the design of bioconcrete is a Grade 30, the materials used for casting are calculated based on DOE concrete mix design. Each batch of concrete consists of 3 cubes to determine the average compressive strength. Each batch requires cement $(4.26 \mathrm{~kg})$, Water $(2.1 \mathrm{~kg})$, Sand $(6.96 \mathrm{~kg})$ and coarse aggregate $(11.31 \mathrm{~kg}) .3 \%$ of partial replacement of water by ureolytic bacteria as in Table 2 , batch 2 and 4 consists of $63 \mathrm{~g}$ of ureolytic bacteria. Whereas, $5 \%$ of partial replacement of water by sulphate reduction bacteria as in Table 3, batch 3 and 4 consists of $105 \mathrm{~g}$ of sulphate reduction bacteria. The dry materials are mixed together in a drum mixer before adding water then bacteria. After adequate consistency and workability, the concrete is put into plastic molds and left to dry for 24 hours before removal and dry curing.

\subsection{Compressive strength test}

Compressive strength test was conducted according to BS EN 12390-3 [9]. The cube specimens of dimensions $150 \mathrm{~mm} \times 150 \mathrm{~mm} \times 150 \mathrm{~mm}$ were tested using Universal Testing Machine (UTM). The specimens were tested at the mature age of 28 days after curing. All batches were tested in triplicates and the average results of these triplicates are presented and discussed.

\section{Results and Discussion}

The average result of the compressive strength of bioconcrete are shown in Table 2 and Figure 3. Where, it shows that concrete in batch 3 has the highest compressive strength which is $42.4 \mathrm{Mpa}$. This batch contains $5 \%$ of Bacillus SP. Batch 1 is the batch that does not contain any bacteria as it is the control and therefore use as a comparative among the 4 batches. The maximum strength of batch 1 is $36 \mathrm{MPa}$. The second highest compressive strength is of Batch 4 . This batch contains both $5 \%$ of 
Bacillus SP and 3\% Enterococcus faecalis. The maximum strength of batch 4 is $40.6 \mathrm{MPa}$. As seen in Figure 2, the batch that contains both bacteria does slightly better comparatively to the stand alone bacteria in batch 2 and control. Batch 2 is concrete with $3 \%$ of Enterococcus faecalis, it has a maximum strength $38.2 \mathrm{MPa}$. The strength enhancement due to the addition of bacteria is because of the deposition of $\mathrm{CaCO}_{3}$ on the concrete pores. As bacteria has the ability to precipitate calcium carbonate in calcite form.

Table 2. Result of compressive strength.

\begin{tabular}{|c|c|c|}
\hline Batch No. & Description & $\mathbf{2 8}^{\text {th }}$ day (MPa) \\
\hline Batch 1 & Control & 36.0 \\
\hline Batch 2 & $\begin{array}{c}\text { Ureolytic bacteria/ } \\
\text { Enterococcus faecalis }\end{array}$ & 38.2 \\
\hline Batch 3 & $\begin{array}{c}\text { Sulphate reduction bacteria/ } \\
\text { Bacillus SP }\end{array}$ & 42.4 \\
\hline Batch 4 & $\begin{array}{c}\text { Ureolytic + Sulphate } \\
\text { reduction bacteria/ } \\
\text { Enterococcus faecalis }+ \\
\text { Bacillus SP }\end{array}$ & 40.6 \\
\hline
\end{tabular}

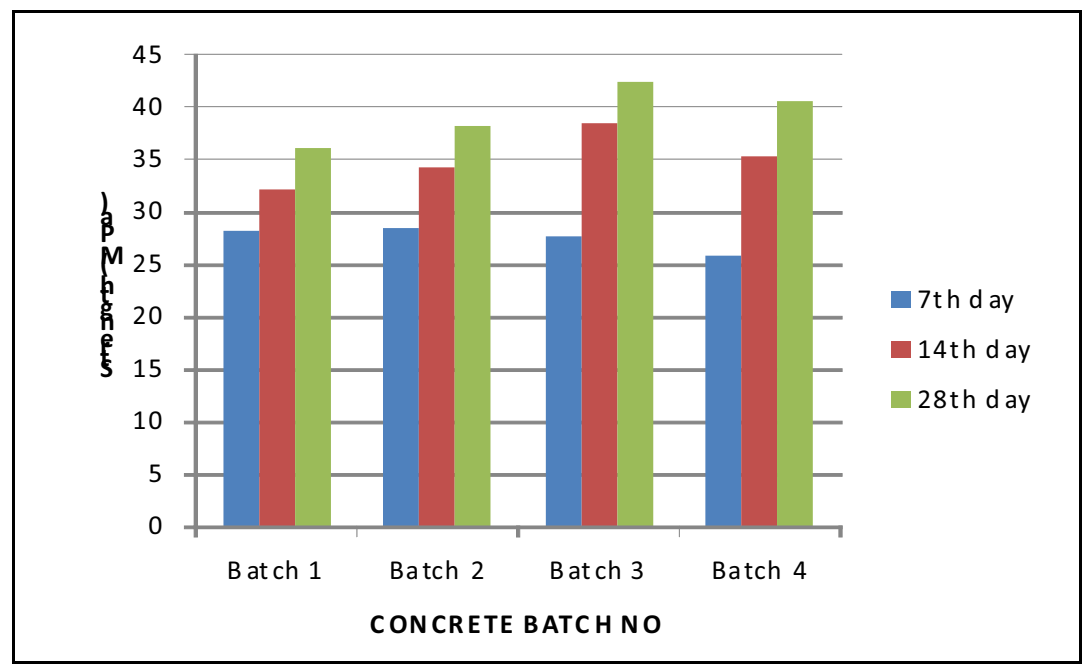

Figure 3. Compressive strength (MPa).

\section{Conclusions}

In this study, the species of bacteria used has been successfully identified as Bacillus $S P$ and Enterococcus faecalis. The use of 3\% of Enterococcus faecalis and 5\% of Bacillus SP is based on an experimental study of using $1 \%, 3 \%$ and $5 \%$ of both bacteria. It was found that $3 \%$ of Enterococcus faecalis and 5\% of Bacillus SP has the highest compressive strength. Adding both types of bacteria into a single batch of concrete proves that even though the 2 bacteria are of different sources and therefore have different characteristics. There are still able to precipitate calcium carbonate thus increasing the compressive strength. Further study should be conducted through various other mechanical tests as well as conducting study regarding the healing capability of these bacteria on concrete. 


\section{References}

[1] P. Ghosh and S. Mandal, Development of bioconcrete material using an enrichment culture of novel thermophilic anaerobic bacteria, Indian J. of Experimental Biology, 44, 336-339, (2006).

[2] W.D. Muynck, K. Cox, N.D. Belie and W. Verstraete, Bacterial carbonate precipitation as an alternate surface treatment for concrete, Construction and Building Materials, 22, 875-885, (2008).

[3] T. Kim,Van, N. De Belie, W. De Muynck and W. Verstrate. Use of bacteria to repair cracks in concrete, Cement and Concrete Research, 40, 157-166, (2010).

[4] K.D. Arunachalan, K.S. Sathyanarayanan, B.S. Darshan and R.B. Raja, Studies on the characterisation of biosealant properties of Bacillus Sphaericus, International J. of Engineering Science and Technology, 2(3), 270-277, (2010).

[5] S.K. Ramachandran, V. Ramakrishnan and S.S. Bang, Remediation of concrete using microorganisms, American Concrete Institute Materials Journal, 98(1), 3-9, (2001).

[6] J.M. Irwan, A. Faisal Alshalif, N. Othman and R.M. Asyraf, Isolation of ureolytic and sulphate reduction bacteria: Acclimitize to concrete environment, International Conference on Civil, Biological and Environmental Engineering, Istanbul, Turkey, (2014).

[7] J.M. Irwan, A. Faisal Alshalif, N. Othman and L.H. Anneza, Effext of Ureolytic Bacteria on compressive strength and water permeability on bio-concrete, International Conference on Civil, Architectural, Structural and Construction Engineering, Seoul, Korea, (2015).

[8] BS 882, Specification for aggregates from natural sources for concrete, British Standard Institution, London, (1992).

[9] BS EN 12390. Part 3: Compressive strength of test specimens, British Standard Institution, London, (2009). 